\title{
Acidity Reduction Of Bio-Oil By Methylic Esterification Reactions
}

\author{
Gabriel Henrique Wienhage ${ }^{\mathrm{a}}$, Eloá Suelen Ramos ${ }^{\mathrm{a}}$, Luana Marcele Chiarello ${ }^{\mathrm{a}}$, Vanderleia Botton ${ }^{\mathrm{a}}$ and Vinicyus \\ Rodolfo Wiggers ${ }^{\mathrm{a}}$ \\ ${ }^{a}$ Department of Chemical Engineering, University of Blumenau, Blumenau, SC, Brazil
}

\section{ARTICLE INFO}

\section{Keywords:}

Upgrading,

esterification,

neutralization,

thermal

cracking,

triglycerides.
An alternative to fossil fuels is the use of triglyceride biomass for conversion to biofuel by the thermal cracking process, also known as pyrolysis. The liquid phase, called bio-oil, has physicochemical properties like petroleum-derived fuels. One of the undesirable characteristics of bio-oil is the high acidity index, due to the presence of short-chain carboxylic acids in its composition. This feature makes refining and use inviable. The objective of this work was to perform esterification reactions using bio-oil, produced from soybean oil pyrolysis already characterized, in order to reduce its acidity index. Besides that, the esterified bio-oil was submitted to different washing experiments to decrease even more the final acidity. For the esterification reaction $25 \mathrm{~g}$ of bio-oil was used at a temperature of $64{ }^{\circ} \mathrm{C}$, using from 0.8 to $2.2 \%$ sulfuric acid and 0.5 to $99.5 \%$ mass ratio of methyl alcohol and bio-oil. The highest acidity index reduction after $20 \mathrm{~min}$ was $81.2 \%$, the esterified bio-oil reduced from 129 to $32.4 \mathrm{mg} \mathrm{KOH} \mathrm{g}^{-1}$. Esterification reaction followed by washing and neutralization can decrease even more those values and, the acidity index can reach zero.

\section{Introduction}

Brazilian government has an initiative to explore and diffuse fossil alternative fuels, called RenovaBio. One of main objectives of this national biofuel policy is to contribute to meeting the country's commitments under the Paris Agreement under the United Nations Framework Convention on Climate Change, according to Law $13.576 / 2017$.

Biomass is an important renewable material, as it can be converted to numerous forms of energy by several processes, depending on the raw material characteristics and the type of product desired ${ }^{[1]}$. One example is pyrolysis, which consists in a thermochemical decomposition of the biomass into hydrocarbon-rich products, biooil, coke and non-condensable gas ${ }^{[2]}$. It can be performed either with or without a catalyst ${ }^{[3]}$, so-called catalytic cracking and catalytic pyrolysis or thermal cracking reactions, respectively ${ }^{[4,5]}$.

Different lignocellulosic (LC) or triacylglycerol (TAG) materials can be employed as feedstock to produce bio-oil, such as from animal fats from food industrial processing ${ }^{[6]}$ lignin and waste cooking oil ${ }^{[7]}$, waste frying oil ${ }^{[8-11]}$, soap from brown grease ${ }^{[12]}$, waste fish fats ${ }^{[13]}$, castor oil ${ }^{[14-16]}$ or soybean oil ${ }^{[17]}$. TAG from vegetable oils is also a low-cost feedstock in some cases. Although bio-oil produced from TAG sources presents advantages in comparison to LC bio-oil, as lower water and oxygen content, and a higher gross calorific value, it also has some drawbacks that reduce its employment as a drop-in liquid fuel ${ }^{[18]}$.
Some inconvenient properties such as high olefin and oxygen contents and a high acidity index (Al), create barriers to its full development and production at industrial scale ${ }^{[19]}$.

Several works in literature presents crude bio-oil produced from TAG as a viable source of renewable hydrocarbons and green chemicals ${ }^{[1,10,19-}$ ${ }^{21]}$. Studies evaluating operational conditions ${ }^{[10]}$, products yielding ${ }^{[6]}$, catalysts ${ }^{[22]}$, reactor type ${ }^{[23]}$, distillation of the crude bio-oil to obtain the heavy and light fractions ${ }^{[24]}$ and products composition ${ }^{[6,25,26]}$ show that is technically viable to obtain an organic liquid product rich in paraffins, i-paraffins, olefins, naphthenes and aromatics in a wide range of carbon chain size.

Olefinic hydrocarbons are essentially produced by decarbonylation reactions in the triglyceride ${ }^{[27]}$. Olefins are associated with poor stability, as well as causing gum or others insoluble materials formation ${ }^{[28]}$. There are many oxygenated organic compounds in bio-oil, as aldehydes, ketones and carboxylic acids, the last being responsible for higher acidity indexes in bio-oil ${ }^{[18]}$. High acidity index measured by free fatty acid content, can lead to corrosion and also affect the cold properties of the biofuel, such as the cold filter plugging and freezing points ${ }^{[11]}$. Table 1 shows some of the studies in the literature about thermal and catalytic cracking, with the respective Al presented by the authors. 
Table 1. Triacylglycerol and bio-oil acidity indexes presented by several studies in the literature.

\begin{tabular}{|c|c|c|c|c|c|c|c|}
\hline \multirow[b]{2}{*}{ Raw material } & \multirow[b]{2}{*}{ Catalyst } & \multirow[b]{2}{*}{ 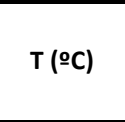 } & \multicolumn{4}{|c|}{ Acidity index $\left(\mathrm{mg} \mathrm{KOH}^{-1}\right)$} & \multirow[b]{2}{*}{ References } \\
\hline & & & $\begin{array}{c}\text { Raw } \\
\text { material }\end{array}$ & $\begin{array}{l}\text { Crude } \\
\text { bio-oil }\end{array}$ & $\begin{array}{l}\text { Light } \\
\text { fraction }\end{array}$ & $\begin{array}{l}\text { Heavy } \\
\text { fraction }\end{array}$ & \\
\hline \multirow{3}{*}{ Waste fish oil } & - & 525 & - & 132.5 & $7.6-172.7$ & $86.9-151.1$ & [29] \\
\hline & - & 500 & - & 103.14 & - & - & [13] \\
\hline & - & 525 & 28.4 & 131.1 & 107.3 & 142.5 & [24] \\
\hline \multirow{2}{*}{ Palm oil } & $\mathrm{Na}_{2} \mathrm{CO}_{3}$ & 450 & - & $1.26-51.56$ & - & - & [30] \\
\hline & $\mathrm{CaO}$ & 480 & - & 58 & - & - & [31] \\
\hline Tung oil & $\mathrm{CaO}$ & 480 & - & 59 & - & - & {$[31]$} \\
\hline Curcas oil & $\mathrm{CaO}$ & 480 & - & 51 & - & - & {$[31]$} \\
\hline Terminalia catappa L. oil & - & 400 & 10.5 & 150.9 & - & - & {$[32]$} \\
\hline Carapa guianensis oil & - & 400 & 36.1 & 143.2 & - & - & [32] \\
\hline Schisandra wilsoniana Sojak oil & $\mathrm{CaO}$ & 480 & - & 77 & - & - & {$[31]$} \\
\hline Plant acidified oil & - & 600 & 135.0 & - & - & - & [33] \\
\hline $\begin{array}{l}\text { Soybean oil }(90 \%, \text { weight }) \text { and } \\
\text { Hydrogenated fat }(10 \%, w)\end{array}$ & - & 525 & - & 195.5 & - & - & [25] \\
\hline $\begin{array}{l}\text { Soybean oil }(80 \%, \text { weigth) and } \\
\text { Hydrogenated fat }(20 \%, w)\end{array}$ & - & 525 & - & 137.0 & - & - & [25] \\
\hline \multirow{6}{*}{ Soybean oil } & - & 500 & 0.08 & 107.87 & - & - & {$[31]$} \\
\hline & - & 340 & - & - & 83 & 111 & [31] \\
\hline & $\mathrm{CaO}$ & 340 & - & - & 67.5 & 104.4 & [31] \\
\hline & $\mathrm{Na}_{2} \mathrm{CO}_{3}$ & 340 & - & - & 44 & 64 & [31] \\
\hline & - & 525 & - & 210.9 & - & - & [34] \\
\hline & & 525 & & 210.9 & - & - & [25] \\
\hline \multirow{7}{*}{ Waste cooking oil } & - & 500 & 9.5 & 115.73 & - & - & [11] \\
\hline & $\mathrm{CaO}$ & 500 & 9.5 & 0 & 1.2 & 0.5 & [11] \\
\hline & - & 500 & - & 124.56 & - & - & [9] \\
\hline & - & $475-525$ & 23.8 & - & $113.8-175.9$ & - & [35] \\
\hline & & 475 & 1.55 & & $22.6-27.7$ & $23.5-30.8$ & [8] \\
\hline & TSS* & 500 & 1.55 & - & 14.7 & 23.2 & [8] \\
\hline & & 525 & 1.55 & & $12.8-26.8$ & $12.4-25.4$ & [8] \\
\hline Poultry fatty waste & - & 500 & - & 124.34 & - & - & [6] \\
\hline Swine fatty waste & - & 500 & - & 138.95 & - & - & [6] \\
\hline
\end{tabular}

*TTS= Textile Stamping Sludge

These studies demonstrated that bio-oil acidity index is highly affected by biomass type, as well as the process conditions or catalyst employed. Moreover, the level of acidity of bio-oil is a barrier to its application either as a drop-in fuel or for further processing (e.g. distillation in different fractions). Therefore, a dramatical reduction of this property might be considered. Studies with emulsification, hydrotreating, reactive distillation and esterification of bio-oil had been reported as methods to improve its characteristics.

Upgrading of bio-oil through emulsification with diesel provides a short-term approach to the use of bio-oil in diesel engines as well as reduce the viscosity of biomass-derived oil ${ }^{[1]}$. Although most part of the literature is reported to LC bio-oil, it can also be applied to TAG bio-oil. However, only small amounts of bio-oil can be emulsified on diesel, not solving the whole problem. Another barrier is that several fuel properties such as heating value, cetane index and corrosivity are reported not suitable. Additionally, injectors and fuel pumps design and production must be necessarily made from stainless steel or other corrosion resistant materials ${ }^{[36]}$

Hydrotreating is commonly employed in a petroleum refinery to remove sulfur, nitrogen, and oxygen from the oil derivates ${ }^{[37]}$. It could be adapted to bio-oil upgrading to deal with oxygen removal and double bonds saturation on olefinic compounds as proposed in Chiarello et al. ${ }^{[38]}$. Nonetheless, the hydrogen consumption in this kind of reaction still needs further evaluation once it could impact in excessive costs ${ }^{[39]}$.
Reactive distillation consists of a separation process combined with chemical reactions through some stages of the distillation column. Some studies in the literature explored this process to different types of TAG bio-oil, obtaining considerably reductions of $\mathrm{Al}^{[29,40,41]}$.

However, hydrotreating and reactive distillation processes can reduce the $\mathrm{Al}$ of crude bio-oil, the acidity can damage the equipment, so it is very important that this property might be properly treated before the distillation column in an additional process ${ }^{[39]}$

Alternatively, esterification reaction can be used to convert unwanted carboxylic acids present in crude bio-oil. In this reaction, an alcohol reacts with carboxylic acids to form esters. The esters produced in the reaction are less reactive and corrosive than their respective carboxylic acids, reducing bio-oil acidity and improving its quality. Typically, methanol or ethanol are employed, yet $n$-butanol have also been studied ${ }^{[31]}$.

Back in 1996, a patent from Radlein, Piskorz, and Majerski ${ }^{[42]}$ have already investigated the esterification and acetalization of lignocellulosic biomasses with alcohol as a solvent. They showed an improvement in the viscosity, acidity, volatility and heating value of the bio-oil. Therefore, bio-oil esterification shows a promising technique to improve bio-oil properties such as acidity index and viscosity as well as promotes its stability ${ }^{[43]}$. On the other hand, there are only a few studies regarding the esterification of bio-oil from TAG sources ${ }^{[4,26,31,41,44,45]}$. The objective of this study is to explore the esterification of bio-oil from soybean oil aiming on best reaction operational conditions. 


\section{Methodology}

\subsection{Thermal Cracking of Commercial Soybean Oil}

The bio-oil used in this work was produced by Ramos et al. ${ }^{[46]}$ from the thermal cracking of commercial soybean oil at $525 \stackrel{\circ}{ } \mathrm{C}$, with a feed rate of $353.4 \mathrm{~g} / \mathrm{h}$ and a residence time of approximately 4.44 $\mathrm{s}$. This process took place in a bench scale auger reactor built in stainless steel with $920 \mathrm{~mm}$ in length and $25 \mathrm{~mm}$ in internal diameter, under isothermal conditions, steady state and continuous operation regime, as describe by details of the reactor can be found in Botton et al. ${ }^{[8]}$

\subsection{Esterification Reactions}

The esterification reactions were performed at 64 oC out in $200 \mathrm{~mL}$ round bottom flask connected to a reflux condenser (Figure 1), the reaction medium used was crude bio-oil (BO), methyl alcohol (99.9\%) and sulfuric acid (95.0\%) as catalyst.

The experimental procedure consisted of adding crude bio-oil and methanol in a $200 \mathrm{~mL}$ round flask at room temperature (around 25 으) in a water bath at $64 \stackrel{\circ}{\circ}$, followed by heating on a hot plate with a magnetic stirrer until constant temperature. Reflux condensers were added to the vessel. When the mixture reached the desired temperature, $0.1 \mathrm{~g}$ sample was collected to measure the acidity at the starting point of the reaction followed by sulfuric acid addition. At fixed intervals, 10 and $20 \mathrm{~min}$, sample of $0.1 \mathrm{~g}$ were collected and analyzed for the acidity to accompany the acidity index reduction in a triplicate analysis. The acidity of the bio-oil was tested according to ASTM D 974. Total reaction time was 20 min for all experiments.



Figure 1. Flowchart with all steps involved in the acidity index reduction.

The mass of bio-oil used was fixed in $25 \mathrm{~g}$, and the percent of sulfuric acid and methanol varied according to the experimental design. A central composite rotatable design that was based on a $2^{2}$ factorial design (Table 2) whose limits were 1 and $2 \%$ for catalyst, and 15 and $85 \%$ for reactants mass ratio, with triplicate at center point was used to optimize the conditions for esterification of bio-oil.

Table 2. Factorial design reaction conditions for acid esterification of the crude bio-oil.

\begin{tabular}{|c|c|c|c|}
\hline \multicolumn{2}{|c|}{ Runs } & \multirow{2}{*}{$\frac{\text { Catalyst (\%) }}{1.0}$} & \multirow{2}{*}{$\frac{\text { Mass ratio (\%) }}{15}$} \\
\hline \multirow{4}{*}{ Corner points } & 1 & & \\
\hline & 2 & 1.0 & 85 \\
\hline & 3 & 2.0 & 15 \\
\hline & 4 & 2.0 & 85 \\
\hline \multirow{4}{*}{ Axial points } & 5 & 0.8 & 50 \\
\hline & 6 & 2.2 & 50 \\
\hline & 7 & 1.5 & 0.5 \\
\hline & 8 & 1.5 & 99.5 \\
\hline \multirow{3}{*}{ Center point } & 9 & 1.5 & 50 \\
\hline & 10 & 1.5 & 50 \\
\hline & 11 & 1.5 & 50 \\
\hline
\end{tabular}

The statistical analysis, Pareto chart, response surface and mathematical model were determined using the software STATISTICA version 10.0. For this purpose, the acidity reduction (\%) obtained after $20 \mathrm{~min}$ of esterification reaction were used as the response function.

\subsection{Washing and Neutralization}

The best condition sample from Table 2 was submitted to three steps washing experiments, initially water washing (1:1 bio-oil:water) followed by neutralization with potassium hydroxide $(\mathrm{KOH})$ and then once again, water washing. The amount of potassium hydroxide used in the second step was quantified according to the bio-oil mass and its respective acidity index. The Al of all phases from each step was performed according to ASTM D 974.

\section{Results and Discussion}

\subsection{Esterification Reactions}

The crude bio-oil produced by Ramos et al. ${ }^{[46]}$ showed an average acidity index of $129 \mathrm{mg} \mathrm{KOH} \mathrm{g}{ }^{-1}$. This bio-oil was subjected to methyl esterification reaction catalyzed by sulfuric acid. The independent variables of experimental design studied were catalyst mass (\%) and molar ratio between ethanol and bio-oil. The Al from Figure 2 suggest that the lowest acidity $\left(19.4^{ \pm 1.4} \mathrm{mg} \mathrm{KOH} \mathrm{g}^{-1}\right)$ were in experiment 8 with $1.5 \%$ catalyst and $99.5 \%$ molar ratio, followed by experiment $4\left(23.1^{ \pm 2.0}\right.$ $\mathrm{mg} \mathrm{KOH} \mathrm{g}^{-1}$ ) with $2 \%$ catalyst and $85 \%$ molar ratio. 


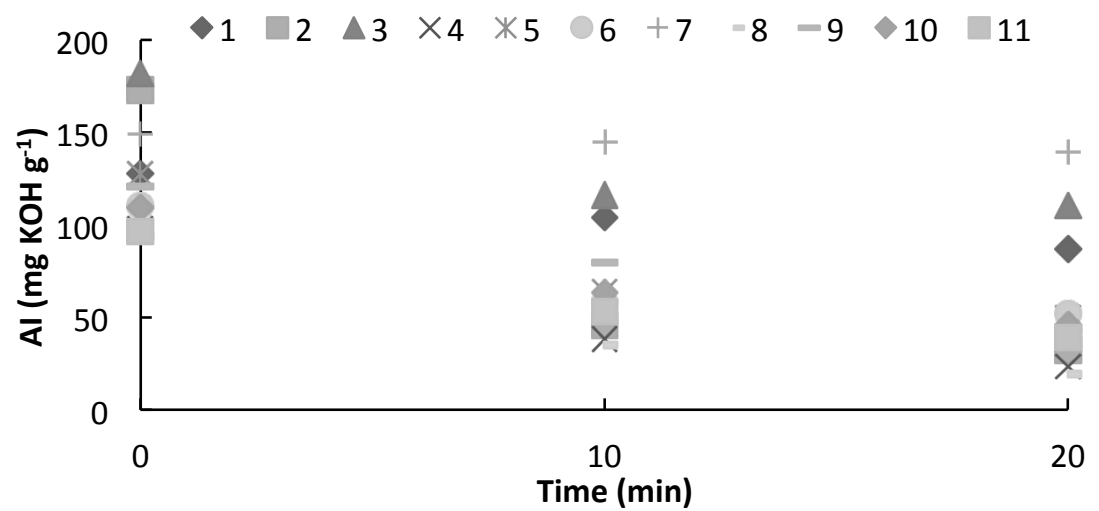

Figure 2. Acidity index (AI) for the esterification of crude bio-oil at different conditions.

The highest $\mathrm{Al}$ reduction in percentage was for experiment $2(81.2 \%)$ after esterification reaction with $1 \%$ catalyst and $85 \%$ molar ratio, as showed in Table 3. While the Al reduction in experiments 8 and 4 were also higher, 79.4 and $76.4 \%$, respectively.

Table 3. Final acidity index (AI) and Al reduction of bio-oils after 20 min reaction.

\begin{tabular}{lcc}
\hline Run & $\begin{array}{c}\text { Final Al } \\
\left.(\mathrm{mg} \mathrm{KOH} \mathrm{g})^{-1}\right)\end{array}$ & $\begin{array}{c}\text { Final Al reduction } \\
(\%)\end{array}$ \\
\hline 1 & $87.1^{ \pm 8.7}$ & 32.0 \\
2 & $32.4^{ \pm 14.0}$ & 81.2 \\
3 & $110.6^{ \pm 20.5}$ & 39.3 \\
4 & $23.1^{ \pm 2.0}$ & 76.4 \\
5 & $49.7^{ \pm 7.2}$ & 61.0 \\
6 & $52.3^{ \pm 4.7}$ & 52.6 \\
7 & $139.2^{ \pm 3.6}$ & 6.7 \\
8 & $19.4^{ \pm 1.4}$ & 79.4 \\
9 & $42.6^{ \pm 4.6}$ & 64.7 \\
10 & $46.0^{ \pm 5.2}$ & 58.0 \\
11 & $39.2^{ \pm 2.8}$ & 59.3 \\
\hline
\end{tabular}

The values from final Al reduction values (\%) were submitted to Analysis of variance (ANOVA) and the results are shown in Table 4. In general, the high $\mathrm{F}$ values found for the regression and the low $\mathrm{F}$ values for the lack of adjustment, in relation to their respective $F_{\text {tab }}$ values, corroborated by the high values of $R^{2}$ and the maximum variances explained.

Table 4. ANOVA using final Al reduction (\%) as response function.

\begin{tabular}{llllll}
\hline FONTE & $\mathbf{S S}^{\mathrm{a}}$ & $\mathbf{D F}^{\mathrm{b}}$ & $\mathbf{M S}^{\mathrm{c}}$ & $\mathbf{F}^{\mathrm{d}}$ & $\mathbf{F}_{\text {table }}$ \\
\hline$R^{2}=0.9571$ & \multicolumn{5}{c}{$\%$ Var $=99.50$} \\
\hline Regression & 4793.54 & 1 & 4793.54 & 224.98 & 5.12 \\
Residual & 191.76 & 9 & 21.31 & 19.35 \\
Lack of Fit & 166.51 & 7 & 23.79 & 1.88 & \\
Pure Error & 25.25 & 2 & 12.62 & & \\
\hline Total & 5008.63 & 10 & & & \\
\hline
\end{tabular}

${ }^{a} \mathrm{SS}=$ sum of squares; ${ }^{b} \mathrm{DF}=$ degree of freedom; ${ }^{\mathrm{c}} \mathrm{MS}=$ mean square value; ${ }^{\mathrm{d}} \mathrm{F}=$ variance.

The central points of the experimental design resulted in acceptable experimental errors, from 2.2 to $6.6 \%$ in relation to the average value. The equation obtained with the independent variable, the linear and quadratic coefficients and the interaction between catalyst and mass ratio presented below in Equation 1, where the abbreviation Cat is catalyst and MR is molar ratio.

$\mathrm{F}_{\mathrm{Al}}=60.67-2.34 *$ Cat $-0.22 * \mathrm{Cat}^{2}+47.28 * \mathrm{MR}-13.97 * \mathrm{MR}^{2}-6.05 * \mathrm{Cat}^{*} \mathrm{MR}$ (1)
The Pareto chart from Figure 3 was used to visualize the numerical significance of the observed trends, expressing the statistical effects in relation to the $\mathrm{p}$ value for the degree of freedom of the experiments carried out in a $95 \%$ confidence interval. The effect of mass ratio, both linear and quadratic, were significant. However, the interaction effect (CatxMR) and the catalyst coefficients had no statistical relevance. 


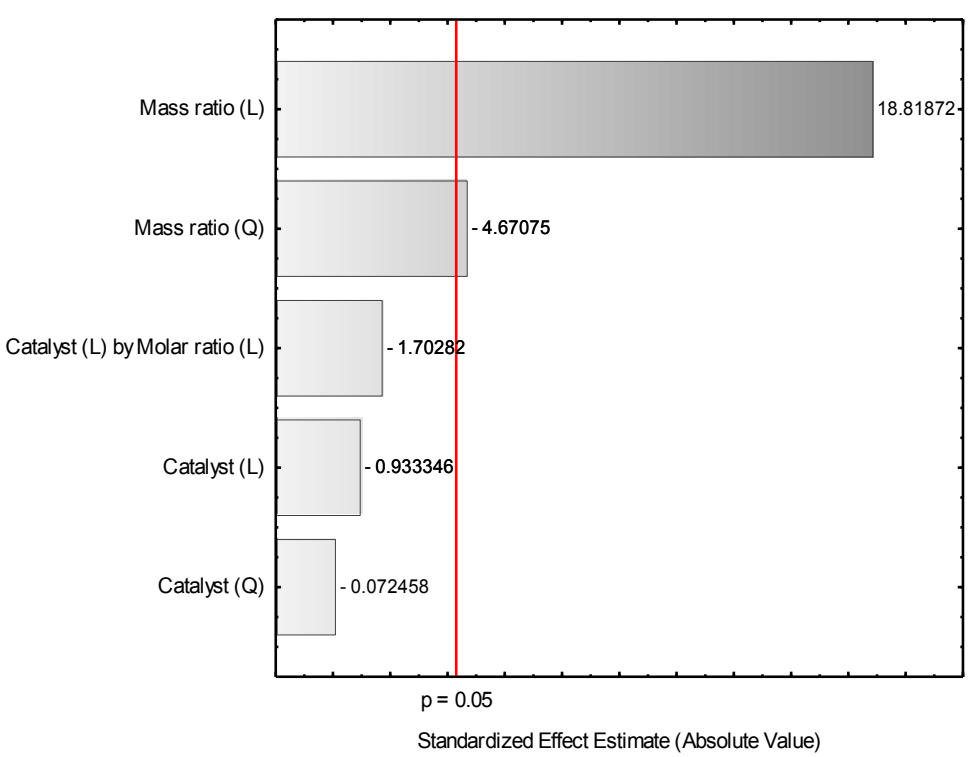

Figure 3. Pareto chart from final acidity index (Al) reduction (\%) experiments.

The data derived from the experimental design were also organized in the form of a contour curve. As indicated in the Figure 4, the region where the values showed high conversion occurred when mass ratio higher than $50 \%$ was used.

The best data of Al reduction obtained in this work, experiments 2 and 4, were compared with those from literature, as showed in Table 5. Although, in this work the reaction conditions were milder, for instance time is far shorter, it was achieved similar results at $20 \mathrm{~min}$ instead of hours. Some papers did not inform if the alcohol was evaporated after the esterification reaction, for instance $\mathrm{Xu}$ et al. ${ }^{[31]}$; Li et al. ${ }^{[44]}$ and Yu et al. ${ }^{[47]}$. In the work of Ramos et al. ${ }^{[46]}$ and in this work, the methanol evaporation was not performed after the esterification reactions. Therefore, it must be considered that the acidity of bio-oil it will slightly increase after alcohol removal.

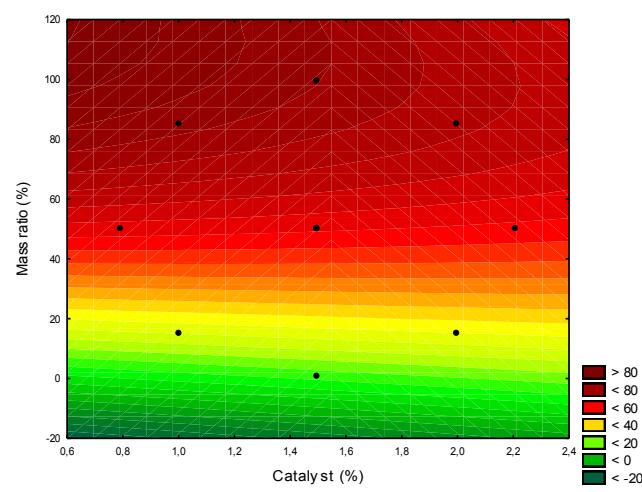

Figure 4. Contour curve from final Al reduction (\%) experiments.

Table 5. Comparison from literature acidity indexes (Al) before and after esterification reactions.

\begin{tabular}{|c|c|c|c|c|c|c|}
\hline \multirow{2}{*}{ Raw material } & \multirow{2}{*}{$\begin{array}{c}\text { Reaction system } \\
\text { (reactant / catalyst) }\end{array}$} & \multirow{2}{*}{ Conditions } & \multicolumn{2}{|c|}{ Acidity index $\left(\mathrm{mg} \mathrm{KOHg}^{-1}\right)$} & \multirow{2}{*}{$\begin{array}{l}\text { Al reduction } \\
(\%)\end{array}$} & \multirow{2}{*}{ References } \\
\hline & & & Before reaction & After reaction & & \\
\hline \multirow{6}{*}{ Soybean oil } & \multirow{2}{*}{ Methanol / $\mathrm{H}_{2} \mathrm{SO}_{4}$} & $64 \stackrel{\circ}{\circ}-20 \min ^{a}$ & $173,1^{ \pm 11.2}$ & $32.4^{ \pm 14.0}$ & 81.2 & \multirow[t]{2}{*}{ This work } \\
\hline & & $64 \stackrel{\circ}{\circ}-20 \min ^{b}$ & $93,9^{ \pm 11.2}$ & $19.4^{ \pm 1.4}$ & 79.4 & \\
\hline & Methanol / $\mathrm{NaHSO}_{4}$ & \multirow{2}{*}{$70 \stackrel{\circ}{ }-2 h$} & $36.9^{c}$ & $3.2^{c}$ & 91.3 & \multirow[t]{2}{*}{ [31] } \\
\hline & Butanol / $\mathrm{NaHSO}_{4}$ & & $30.1^{d}$ & $3.3^{d}$ & 89.0 & \\
\hline & Methanol $/ \mathrm{H}_{2} \mathrm{SO}_{4}$ & $65 \stackrel{\circ}{\circ}-90 \mathrm{~min}$ & 133.3 & $3.4^{ \pm 0.5}$ & 97.5 & \multirow[t]{2}{*}[46]{} \\
\hline & Ethanol / $\mathrm{H}_{2} \mathrm{SO}_{4}$ & $75 \stackrel{\circ}{ } \mathrm{C}-90 \mathrm{~min}$ & 133.3 & $12.6^{ \pm 0.7}$ & 90.4 & \\
\hline \multirow{3}{*}{ Rubber seed oil } & Methanol $/ \mathrm{Zr}\left(\mathrm{SO}_{4}\right)_{2}$ & & $97.0^{ \pm 1.2}$ & $1.2^{ \pm 1.0}$ & 98.8 & \multirow{3}{*}{ [44] } \\
\hline & Methanol / $\mathrm{Zr}\left(\mathrm{NO}_{3}\right)_{4}$ & $100 \stackrel{\circ}{ }-4 h$ & $99.6^{ \pm 1.1}$ & $32.9^{ \pm 1.3}$ & 67.0 & \\
\hline & Methanol / $\mathrm{ZrOCl}_{2}$ & & $99.6^{ \pm 1.4}$ & $57.0^{ \pm 1.2}$ & 42.8 & \\
\hline \multirow{3}{*}{ Waste cooking oil } & Methanol / $\mathrm{H}_{2} \mathrm{SO}_{4}$ & & 70.3 & 4.7 & 93.3 & \multirow{3}{*}[47]{} \\
\hline & Methanol / $\mathrm{Na}_{2} \mathrm{CO}_{3}$ & $100 \stackrel{\circ}{\circ}-6 h$ & 70.3 & 5.7 & 92.0 & \\
\hline & Methanol / $\mathrm{SO}_{4}{ }^{2-} / \mathrm{ZrO}_{2}$ & & 70.6 & 2.7 & 96.1 & \\
\hline
\end{tabular}

${ }^{\mathrm{a}}$ Condition 2 from Table $2 ;{ }^{b}$ Condition 4 from Table $2 ;{ }^{c}$ Diesel fraction; ${ }^{b}$ Gasoline fraction. 


\subsection{Washing and neutralization}

The remaining bio-oil from experiment 2 (Table 2 ) was submitted to washing experiments divided in three different steps. In the first step, $8.0 \mathrm{~g}$ of bio-oil was washed with $8.0 \mathrm{~g}$ of water and the $\mathrm{Al}$ decreased from 32.45 to $27.20 \mathrm{mg} \mathrm{KOH} \mathrm{g}^{-1}$. The resulting bio-oil was neutralized with a $\mathrm{KOH}$ solution of $0.23 \mathrm{~g} \mathrm{KOH}$ and $7.7 \mathrm{~g}$ water. The IA value for the bio-oil and water phase zeroed after this second step. Later, another water washing step was performed with the $8.0 \mathrm{~g}$ of bio-oil together with $8.0 \mathrm{~g}$ of water, aiming to remove all the potassium hydroxide present in the sample. The acidity index was once again zero in both phases for all samples after this third washing step. Therefore, it is possible to conclude that esterification followed by washing and neutralization can reduce to zero the acidity of bio-oil.

\section{Conclusions}

The bio-oil obtained through the thermal cracking process has several properties, one of which is its high acidity index. The methyl esterification reaction can be one of the alternatives for reducing the acidity index followed by a base neutralization and water washing. It was possible to observe that the amount of alcohol used in the esterification reaction significantly interferes in the reduction of the acidity index, that is, a greater amount of methanol results in a greater reduction in the acidity index. The best results were with experiments 2, 8 and 4 with $81.2,79.4$ and $76.4 \%$ final acidity reduction, achieving 32.4, 23.1 and $19.4 \mathrm{mg} \mathrm{KOH} \mathrm{g}^{-1}$, respectively. Esterification reaction followed by washing and neutralization performed in sample 2 can decrease even more those values and, the acidity index can reach zero.

\section{Acknowledgements}

The authors are grateful to the reviewers, to PIBIC/CNPq/FURB for the support through the Institutional Program of Fellowships of Scientific Initiation $N^{\circ}-359 / 2019$, to CNPq (Conselho Nacional de Desenvolvimento Científico e Tecnológico, Brazil) processes no. 304560/2020-0). This study was financed in part by the Coordenação de Aperfeiçoamento de Pessoal de Nível Superior - Brasil (CAPES) Finance Code 001.

\section{Declaration of interest}

The authors declare that they have no known competing financial interests or personal relationships that could have appeared to influence the work reported in this paper.

\section{References}

[1] Makarfi Isa, Y.; Ganda, E. T. (2018). Bio-oil as a potential source of petroleum range fuels. Renew. Sustain. Energy Rev., pages 69- 75.

[2] Beims, R. F.; Simonato, C. L.; Wiggers, V. R. (2019). Technology readiness level assessment of pyrolysis of trygliceride biomass to fuels and chemicals. Renew. Sustain. Energy Rev., pages 521 - 529.

[3] Molefe, M.; Nkazi, D.; Mukaya, H. E. (2019). Method Selection for Biojet and Biogasoline Fuel Production from Castor Oil: A Review. Energy \& Fuels, pages 5918 - 5932.

[4] Xu, J.; Jiang, J.; Zhang, T.; Dai, W. (2013). Biofuel production from catalytic cracking of triglyceride materials followed by an esterification reaction in a scale-up reactor. Energy and Fuels, pages $255-261$.

[5] Shitao, Y.; Cao, X.; Wu, S.; Chen, Q.; Li, L.; Li, H. (2020). Effective pyrolysis of waste cooking oils into hydrocarbon rich biofuel on novel mesoporous catalyst with acid and alkali coexisting. Ind. Crops Prod., pages 112362.

[6] Hassen-Trabelsi, A. B.; Kraiem, T.; Naoui, S.; Belayouni, H. (2014). Pyrolysis of waste animal fats in a fixed-bed reactor: Production and characterization of bio-oil and bio-char. Waste Manag., pages $210-$ 218.

[7] Fan, L.; Ruan, R.; Li, J.; Ma, L.; Wang, C.; Zhou, W. (2020). Aromatics production from fast co-pyrolysis of lignin and waste cooking oil catalyzed by HZSM-5 zeolite. Appl. Energy, pages 114629.
[8] Botton, V.; Riva, D.; Simionatto, E. L.; Wiggers, V. R.; Ender, L.; Meier, H. F.; Barros, A. A. C. (2012). Craqueamento termo-catalítico da mistura óleo de fritura usado - Lodo de estamparia têxtil para a produção de óleo com baixo índice de acidez. Quim. Nova, pages 677 $-682$.

[9] Kraiem, T.; Hassen, A. Ben; Belayouni, H.; Jeguirim, M. (2017). Production and characterization of bio-oil from the pyrolysis of waste frying oil. Environ. Sci. Pollut. Res., pages 9951 - 9961.

[10] Trabelsi, A. B. H.; Zaafouri, K.; Baghdadi, W.; Naoui, S.; Ouerghi, A. (2018). Second generation biofuels production from waste cooking oil via pyrolysis process. Renew. Energy, pages $888-896$.

[11] Chang, J.-S.; Cheng, J.-C.; Ling, T.-R.; Chern, J.-M.; Wang, G.-B.; Chou, T.-C.; Kuo, C.-T. (2017). Low acid value bio-gasoline and biodiesel made from waste cooking oils using a fast pyrolysis process. J. Taiwan Inst. Chem. Eng, pages $1-11$.

[12] Ratton Coppos, A. R.; Kahn, S.; Borges, L. E. P. (2018). Biofuels production by thermal cracking of soap from brown grease. Ind. Crops Prod., pages $561-568$.

[13] Kraiem, T.; Hassen-Trabelsi, A. Ben; Naoui, S.; Belayouni, H.; Jeguirim, M. (2015). Characterization of the liquid products obtained from Tunisian waste fish fats using the pyrolysis process. Fuel Process. Technol., pages $404-412$.

[14] Menshhein, G.; Costa, V.; Chiarello, L. M.; Scharf, D. R.; Simionato, E. L.; Botton, V.; Meier, H. F.; Wiggers, V. R.; Ender, L. (2019). Concentration of renewable products of crude bio-oil from thermal cracking of the methyl esters in castor oil. Renew. Energy, pages 561 -568 .

[15] Menshhein, G.; Costa, V.; Chiarello, L. M.; Scharf, D. R.; Simionato, E. L.; Botton, V.; Meier, H. F.; Wiggers, V. R.; Ender, L. (2019). Experimental data of the distillation of bio-oil from thermal cracking of methyl ester in castor oil. Data Br., pages 104325.

[16] Botton, V.; Torres De Souza, R.; Wiggers, V. R.; Scharf, D. R.; Simionatto, E. L.; Ender, L.; Meier, H. F. (2016). Thermal cracking of methyl esters in castor oil and production of heptaldehyde and methyl undecenoate. J. Anal. Appl. Pyrolysis, page 387 - 393.

[17] Wiggers, V. R.; Meier, H. F.; Wisniewski, A.; Chivanga Barros, A. A.; Wolf Maciel, M. R. (2009). Biofuels from continuous fast pyrolysis of soybean oil: A pilot plant study. Bioresour. Technol., pages $6570-$ 6577.

[18] Stedile, T.; Ender, L.; Meier, H. F.; Simionatto, E. L.; Wiggers, V. R. (2015). Comparison between physical properties and chemical composition of bio-oils derived from lignocellulose and triglyceride sources. Renew. Sustain. Energy Rev., pages $92-108$.

[19] Wiggers, V. R.; Beims, R. F.; Ender, L.; Simionatto, E. L.; Meier, H. F. (2017). Renewable Hydrocarbons from Triglyceride's Thermal Cracking. In Frontiers in Bioenergy and Biofuels; Jacob-Lopes, E., Zepka, L.Q., Eds.; InTech.

[20] Wisniewski, A.; Wiggers, V. R.; Simionatto, E. L.; Meier, H. F.; Barros, A. A. C.; Madureira, L. A. S. (2010). Biofuels from waste fish oil pyrolysis: Chemical composition. Fuel, pages $563-568$.

[21] Xu, J.; Jiang, J.; Zhao, J. (2016). Thermochemical conversion of triglycerides for production of drop-in liquid fuels. Renew. Sustain. Energy Rev., pages $331-340$.

[22] Araújo, A. M. de M.; Lima, R. de O.; Gondim, A. D.; Diniz, J.; Souza, L. Di; Araujo, A. S. de. (2017). Thermal and catalytic pyrolysis of sunflower oil using AIMCM-41. Renew. Energy, pages 900 - 906.

[23] Wetroff, G.; Thillay, L.; Divachetf, G.; Khaladji, J. (1957). Pyrolysis of Ricinoleates.

[24] Beims, R. F.; Botton, V.; Ender, L.; Scharf, D. R.; Simionatto, E. L.; Meier, H. F.; Wiggers, V. R. (2018). Effect of degree of triglyceride unsaturation on aromatics content in bio-oil. Fuel, pages $175-184$.

[25] Suota, M. J.; Simionatto, E. L.; Scharf, D. R.; Meier, H. F.; Wiggers, V. R. (2019). esterification, distillation, and chemical characterization of bio-oil and its fractions. Energy \& Fuels, pages $9886-9894$. 
[26] Silva, V. T.; Sousa, L. A. (2013). Catalytic Upgrading of Fats and Vegetable Oils for the Production of Fuels.

[27] Kumar, N. (2017). Oxidative stability of biodiesel: Causes, effects and prevention. Fuel, pages $328-350$.

[28] Wisniewski Jr., A.; Wosniak, L.; Scharf, D. R.; Wiggers, V. R.; Meier, H. F.; Simionatto, E. L. (2015). Upgrade of biofuels obtained from waste fish oil pyrolysis by reactive distillation. J. Braz. Chem. Soc. pages $224-232$.

[29] Wiggers, V. R.; Wisniewski, A.; Madureira, L. A. S.; Barros, A. A. C.; Meier, H. F. (2009). Biofuels from waste fish oil pyrolysis: Continuous production in a pilot plant. Fuel, pages $2135-2141$.

[30] Mancio, A. A.; Costa, K. M. B. da; Ferreira, C. C.; Santosa, M. C.; Lhamas, D. E. L.; Mota, S. A. P. da; Leão, R. A. C.; Souza, R. O. M. A. de; Araújo, M. E.; Borges, L. E. P. (2016). Thermal catalytic cracking of crude palm oil at pilot scale: Effect of the percentage of $\mathrm{Na} 2 \mathrm{CO} 3$ on the quality of biofuels. Ind. Crops Prod., pages $32-43$.

[31] Xu, J.; Jiang, J.; Sun, Y.; Chen, J. (2010). Production of hydrocarbon fuels from pyrolysis of soybean oils using a basic catalyst. Bioresour. Technol., pages $9803-9806$.

[32] Iha, O. K.; Alves, F. C. S. C.; Suarez, P. A. Z.; Silva, C. R. P.; Meneghetti, M. R.; Meneghetti, S. M. P. (2014). Potential application of Terminalia catappa L. and Carapa guianensis oils for biofuel production: Physical-chemical properties of neat vegetable oils, their methyl-esters and bio-oils (hydrocarbons). Ind. Crops Prod., pages 95 $-98$

[33] Xu, L.; Cheng, J.-H.; Liu, P.; Wang, Q.; Xu, Z.-X.; Liu, Q.; Shen, J.-Y.; Wang, L.-J. (2019). Production of bio-fuel oil from pyrolysis of plant acidified oil. Renew. Energy, pages 910 - 919.

[34] Lima, D. G.; Soares, V. C. D.; Ribeiro, E. B.; Carvalho, D. A.; Cardoso, É. C. V.; Rassi, F. C.; Mundim, K. C.; Rubim, J. C.; Suarez, P. A. Z. (2004). Diesel-like fuel obtained by pyrolysis of vegetable oils. J. Anal. Appl. Pyrolysis, pages 987 - 996.

[35] Wiggers, V. R.; Zonta, G. R.; França, A. P.; Scharf, D. R.; Simionatto, E. L.; Ender, L.; Meier, H. F. (2013). Challenges associated with choosing operational conditions for triglyceride thermal cracking aiming to improve biofuel quality. Fuel, pages $601-608$.
[36] Xiu, S.; Shahbazi, A. (2012). Bio-oil production and upgrading research: A review. Renew. Sustain. Energy Rev., pages 4406-4414.

[37] Huber, G. W.; Corma, A. (2007). Synergies between bio- and oil refineries for the production of fuels from biomass. Angew. Chemie Int. Ed., pages $7184-7201$

[38] Chiarello, L.; Porto, T.; Barros, A.; Simionatto, E.; Botton, V.; Wiggers, V. (2020). Bosting an oil refinery into a biorefinery. Angolan Miner. Oil Gas J., pages 1 - 5 .

[39] Beims, R. F.; Bertoli, S. L.; Botton, V.; Ender, L.; Simionatto, E. L.; Meier, H. F.; Wiggers, V. R. (2017). Co-processing of thermal cracking bio-oil at petroleum refineries. Brazilian J. Pet. Gas, pages $99-113$.

[40] Wang, C.; Hu, Y.; Chen, Q.; Lv, C.; Jia, S. (2013). Bio-oil upgrading by reactive distillation using $\mathrm{p}$-toluene sulfonic acid catalyst loaded on biomass activated carbon. Biomass and Bioenergy, pages 405-411.

[41] Junming, X.; Jianchun, J.; Yunjuan, S.; Yanju, L. (2008). Bio-oil upgrading by means of ethyl ester production in reactive distillation to remove water and to improve storage and fuel characteristics. Biomass and Bioenergy, pages $1056-1061$.

[42] Radlein, D. S. A. G.; Piskorz, J. K.; Majerski, P. A. (1996). Method of upgrading biomass pyrolysis liquids for use as fuels and as a source of chemicals by reaction with alcohols.

[43] Gollakota, A. R. K.; Reddy, M.; Subramanyam, M. D.; Kishore, N. (2016). A review on the upgradation techniques of pyrolysis oil. Renew. Sustain. Energy Rev., pages 1543 - 1568.

[44] Li, L.; Yan, B.; Li, H.; Yu, S.; Ge, X. (2020). Decreasing the acid value of pyrolysis oil via esterification using ZrO2/SBA-15 as a solid acid catalyst. Renew. Energy, pages 643-650.

[45] Kim, J.-H.; Jung, J.-M.; Cho, S.-H.; Tsang, Y.F.; Wang, C.-H.; Lee, J.; Kwon, E.E. (2019). Upgrading bio-heavy oil via esterification of fatty acids and glycerol. J. Clean. Prod., pages 633 - 638.

[46] Ramos, E. S.; Zimmermann, D.; Beims, R. F.; Chiarello, L. M.; Botton, V.; Simionatto, E. L.; Wiggers, V. R. (2020). Evaluation of ethylic and methylic esterification reactions to reduce acidity of crude bio-oil. Environ. Prog. Sustain. Energy, pages 13441.

[47] Yu, S.; Wu, S.; Li, L.; Ge, X. (2020). Upgrading bio-oil from waste cooking oil by esterification using $\mathrm{SO} 42-/ \mathrm{ZrO} 2$ as catalyst. Fuel, pages 118019. 